\title{
上肢切断者の現状と動向 一近畿地区におけるアンケート調査から一
}

\author{
川村 次郎*1 \\ 藤下 武*2 \\ 福井 信佳*2 \\ 中川 正已*2 \\ 青山 孝*3 \\ 古川宏*4

\section{The Upper-limb Amputees -A Survey and Trends in Kinki Area of Japan-}

\author{
Jiro Kawamura, ${ }^{* 1}$ Nobuyoshi Fukui, ${ }^{* 2}$ Masami Nakagawa, ${ }^{* 2}$ \\ Takeshi Fujishita, ${ }^{* 2}$ Takashi Aoyama, ${ }^{* 3}$ Hiroshi Furukawa*4
}

\begin{abstract}
The 1,103 upper-limb amputees who were onfiles in 3 prosthetics facilities in Kinki area of Japan were asked to join our study by mail, of which the 427 amputees answered our questionnaires. The average age of amputees was 55.7 years. Eighty-two percent of amputees were male and 18 percent were female. The average elapsed period from amputation to this survey was 23.7 years. Ninety-two percent of the amputees were caused by trauma (77\% industrial accidents, 7\% traffic accidents, $4 \%$ war, $14 \%$ other accidents), $5 \%$ by congenital amputations, $2 \%$ by diseases, and $1 \%$ by others. Fifty-six percent of the patients occupations at the time of amputation were the manual laborers. Whereas, only $13 \%$ were the manual laborers and $31 \%$ were unemployed at the time of this survey. Level of amputation were classified as follows: shoulder disarticulation (2\%), above-elbow $(32 \%)$, elbow disarticulation $(4 \%)$, below-elbow $(52 \%)$, wrist disarticulation (11\%). Seventeen percent of the unilateral amputees were using two or more types of prostheses. Eighty percent of the amputees were using the cosmetic prostheses, $21 \%$ the body-powered prostheses, $11 \%$ the working prostheses, only $1 \%$ the electrically-powered prostheses, and $4 \%$ no prosthesis. Seventy-six percent of the amputees hoped to use the myoelectric hand. In 110 amputees who were amputated within recent 10 years, the average age of amputation time was 45.9 years, $90 \%$ of the amputees were caused by trauma. Forty-seven percent of them were users of the body-powered prostheses, $16 \%$ the working prostheses, and $2 \%$ the electrically-powered prostheses. In conclusion, the center of living upper-limb amputees were long elapsed, aged male amputees caused by the industrial accidents. In the amputees who received amputation within recent 10 years, main cause of amputation was still industrial injury, many of them were aged already at the time of amputation, and the number of amputees wearing body-powered prostheses was increasing. (Jpn J Rehabil Med 1999 ; 36 : 384-389)
\end{abstract}

要 旨: 上肢切断者 1,103 人にアンケート調査を行い 427 人から回答を得た. 切断者の平均 年齢は 55.7 歳, 男 $82 \%$, 切断からの平均経過年数は 23.7 年, 切断原因は労働災害を主とす

1998 年 8 月 10 日受付, 1999 年 5 月 10 日受理

*1 日下病院/ $7511-0428$ 三重県員弁郡北勢町阿下喜 680

Kusaka Hospital

*2 大阪労災病院リハビリテーション科/テ 591-8501 堺市長曽根町 1179-3

Department of P. M. \& Rehabilitation, Osaka Rosai Hospital

*3 (株) 松本義肢製作所/ $\overline{\mathrm{T}} 461-8555$ 名古屋市東区泉 3-4-3

Matsumoto P \& O Co., LTD.

*4 神戸大学医学部保健学科/ 个 654-0142 神戸市須磨区友が丘 7-10-2

Faculty of Health Science, Kobe University School of Medicine 
る外傷 $92 \%$. 片側切断 418 人中の $4 \%$ は義手を使用せず，使用者の義手の種類は装飾義手 $80 \%$, 能動義手 $21 \%$ ，作業義手 $11 \%$ ，電動義手 $1 \%$ （2 種類以上の義手の使用者が $17 \%$ ）. 筋 電電動義手の装着希望が $76 \%$. 経過 10 年末満の 110 人に限ると, 切断時年齢は平均 45.9 歳, 切断原因は外傷 90\%, 使用義手 は装飾義手 65\%, 能動義手 $47 \%$, 作業義手 $16 \%$, 電動義手 $2 \%$. 現在の上肢切断者は, 労働災害による経過の長い高齢の男性切断者が中心である. 最近 の切断例も労働災害が多く, 切断時点で高歯者が多いが, 約半数は能動義手を使用している。

(リハ医学 $1999 ; 36: 384-389$ )

$\boldsymbol{K} \boldsymbol{e y} \boldsymbol{w o r d s}$ ：上肢切断者（upper-limb amputees）, 疫学調査（epidemiologic research）, 義手（upper-limb prostheses）

\section{はじめに}

新しい義手の開発目標の設定や給付制度の充実を考 えるときに，上肢切断者の実態や義手に対するニーズ を把握しておくことが不可欠である11. しかし上肢切 断者の実態に関する調査は非常に少なく，とくに国内 の全国的・詳細な調査は 1977 年のリ八医学会の調査 を除くとほとんどないのが実状である2).

今回われわれは近畿地区の上肢切断者を対象に郵送 によるアンケート調査を行い, 上肢切断者の年齢, 性, 切断原因, 切断部位, 職業, 使用義手, 義手への 要望などを明らかにするとともに, 切断からの経過が 10 年未満の症例について切断原因, 切断時年齢, 使 用義手を集計し，これまでの内外の報告と比較検討し て, 最近の新しい切断者の動向について述べる.

\section{対象と方法}

近畿地区 (京都, 大阪, 三重, 滋賀, 奈良, 和歌 山，兵庫の 2 府 5 県）の代表的義肢製作会社である 3 社に登録されている手関節離断より近位の上肢切断者 1,103 人を対象に，郵送によるアンケート調査を行っ た. 調査項目は, 性別, 年齢, 切断時年齢, 切断の原 因, 切断部位, 利き手側, 切断時および現在の職業, 現在使用している義手の種類, 義手への希望, 筋電電 動義手の装着希望である．切断部位と現在使用してい る義手の種類については，切断者からの回答に加え て，義肢製作会社の記録も参考にして判断した。

結果の整理にあたって，2 標本の割合の差の検定と 2 標本の平均值の差の検定を行った. 2 標本の割合の 差の検定では，本研究で集められたサンプル数が十分 に大きかったので，正規分布を用いた検定を行った。 本文中の $z$ は得られた標準正規分布の $z$ 得点, $p$ は有 意水準を示す.また 2 標本の平均值の差の検定では $t$ 検定を用いた。本文中の $t$ は得られた $t$ 值， $d_{\mathrm{f}}$ は自
由度， $p$ は有意水準を示す。また， 2 属性の独立性の 検定には $\chi^{2}$ 検定を行った。

\section{結果}

回答があったのは 570 人，死亡が 14 人，住所不明 が 30 人，回答なしが 489 人であった．回答の記載が 不十分な 143 人を除いた有効回答者数は 427 人（回答 率：39\%)，男 352 人 (82\%)，女 75 人 $(18 \%)$ ，片側 切断 418 人, 両側切断 9 人であった.

\section{1. 切断者の年齢}

調査時点の切断者の年齢は 5 89 歳にわたり, 年代 別では 10 歳未満が 3 人 (1\%)，10歳代が 5 人 $(1 \%), 20$ 歳代が 27 人 (6\%)，30 歳代が 27 人 (6\%)，40 歳代が 50 人 (12\%)，50 歳代が 129 人 (30\%)，60 歳代が 109 人 (26\%)，70 歳代以上が 77 人 $(18 \%)$, 平均年齢 55.7 歳（標準偏差 15.3 歳）で あった（図 1).

\section{2. 切断後経過年数}

切断から調查時点までの経過年数は 6 力月〜 67 年 にわたり，10 年末満が 110 人 ( $26 \%) ， 10 〜 19$ 年が 83 人 $(19 \%) ， 20 \sim 29$ 年が 90 人 $(21 \%) ， 30 \sim 39$ 年 が 70 人 $(16 \%) ， 40 \sim 49$ 年が 41 人 $(10 \%) ， 50$ 年以 上が 33 人 $(8 \%)$, 平均 23.7 年（標準偏差 15.8 年）

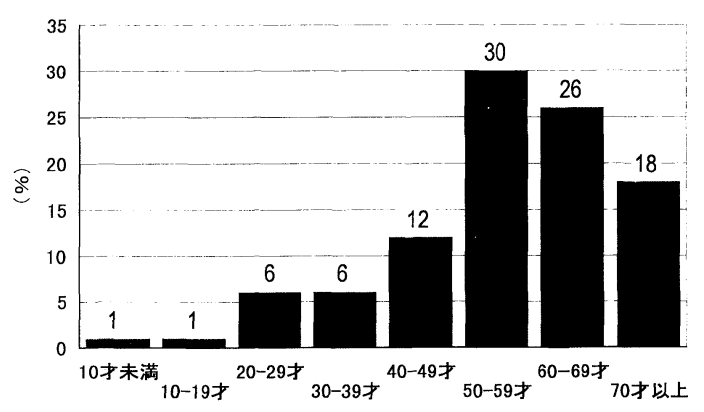

図 1 切断者の年齢 図中の数字は\%を表す。 
であった。

\section{3. 切断原因}

切断原因は労働災害が 285 人 (67\%)，一般事故 61 人 $(14 \%)$, 交通事故 32 人 $(7 \%)$, 戦傷 15 人 $(4 \%)$, 先天性切断 22 人 $(5 \%)$, 疾病 9 人 $(2 \%)$, そのほか 3 人（1\%）であった（図 2).

\section{4. 職業}

切断時の職業は現場労働が 237 人 (56\%), 技術 45 人 $(11 \%)$, 自営（農業 14 人を含む） 31 人 $(7 \%)$, 乳幼児 30 人 $(7 \%)$, 事務 20 人 $(5 \%)$, 学生 19 人 $(5 \%)$, 管理職 15 人 $(4 \%)$, 無職 5 人 (1\%), そのほ か 32 人 (8\%) であった。調查時点では現場労働 55 人 $(13 \%)$, 技術 22 人 $(5 \%)$, 自営 41 人 $(10 \%)$, 乳 幼児 2 人 $(1 \%)$, 事務 59 人 $(14 \%)$, 学生 8 人 $(2 \%)$, 管理職 38 人 $(9 \%)$, 無職 131 人 $(31 \%)$, そ のほか 69 人 (16\%) であった（重複回答あり).

\section{5. 切断部 位}

両側切断例の 9 人は, 両肩関節離断 1 人, 両前腕切 断 5 人, 両手関節離断 1 人, 肩関節離断 + 上腕切断 1 人, 上腕切断十前腕切断 1 人であった.

片側切断例の 418 人は, 右側 233 人 (56\%), 左側 185 人 $(44 \%)$, 利き手側の切断 245 人 $(59 \%)$, 非利 き手側 136 人 $(33 \%)$, 両手利きまたは不明 37 人 (9\%) であった。切断部位は肩関節離断が 8 人 $(2 \%)$, 上腕切断が 132 人 (32\%), 肘関節離断が 15 人 $(4 \%)$, 前腕切断が 216 人 $(52 \%)$, 手関節離断 47 人 $(11 \%)$ であった。

\section{6. 使用義手の種類}

両側切断例は全例が義手を使用しており，両側とも 装飾義手 5 人，両側とも能動義手（フック型） 3 人, 右側が能動義手 (フック型) + 左側が装飾義手が 1 人 であった。

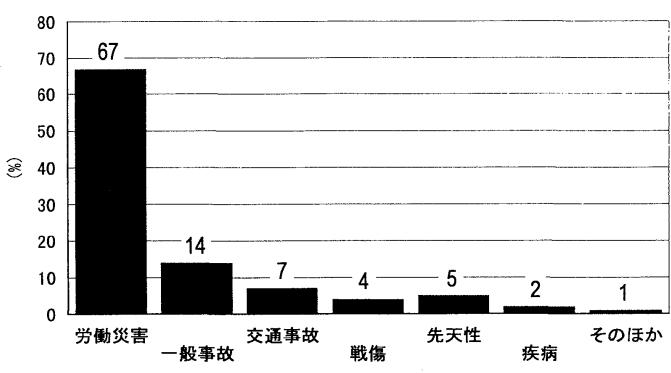

図 2 切断原因 図中の数字は\%を表す。
片側切断例の場合，義手を使用していない例が 15 人 (4\%) あり，403人 $(96 \%)$ が義手を使用してい たが，69人（17\%）は装飾義手と能動義手のように 2 種類以上の義手を使用していた。装飾義手の使用者は 334 人 $(80 \%)$, 能動義手は 86 人 $(21 \%)$, 内ハンド 型能動義手が 46 人 $(11 \%)$ ，フック型能動義手が 40 人 $(10 \%)$, 作業義手は 46 人 $(11 \%)$, 電動義手は 6 人（1\%）であった（重複回答あり）（図 3).

\section{7. 義手への希望}

軽量化を望む人が 247 人 $(58 \%)$ ，手の形に近いも のが 233 人 $(55 \%)$, 污れたら洗える手先具が 190 人 (45\%)，いろいろな握り方ができる手先具が 189 人 (44\%)，手首の迴る義手が 169 人（40\%)，汗をかい ても蒸れないソケット 19 人 (4\%)，もっと義手につ いての情報が欲しい 13 人（3\%）などであった.

筋電電動義手の装着を希望する人は 324 人 $(76 \%)$ あった、筋電電動義手を装着したいと思う理由は，手 の形をしている, 自分の思うとおりに動く, 握る力が 強い，新しい義手だからなどであった。

\section{8. 経過 10 年未満の切断者について}

切断からの経過が 10 年未満の切断者 110 人につい て, 切断原因, 切断時年齢, 使用義手を集計した. 切断原因は労働災害が 64 人 (58\%)，一般事故 19 人 $(17 \%)$, 交通事故 16 人 $(15 \%)$, 戦傷 0 人 $(0 \%)$, 先天性切断 2 人 $(2 \%)$, 疾病 7 人 $(6 \%)$, そのほか 2 人（1\%）であった。

切断時年齢は, 10 歳未満が 3 人 (3\%)，10 19 歳 が 4 人 $(4 \%) ， 20 \sim 29$ 歳が 15 人 (14\%)，30 39 歳 が 10 人 (9\%)，40 49 歳が 27 人 (25\%)，50〜 59 歳 が 30 人 $(27 \%) ， 60 \sim 69$ 歳が 17 人 $(16 \%) ， 70$ 歳以 上が 4 人 $(4 \%)$, 平均 45.9 歳（標準偏差 16.8 歳）で あった（図4).

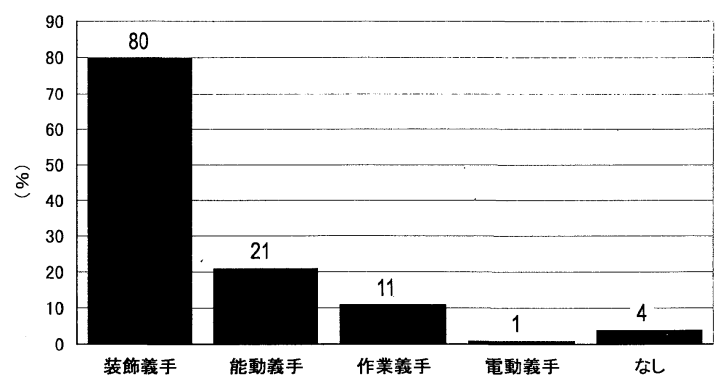

図 3 片側切断者の使用義手 図中の数字は\%を表す。 


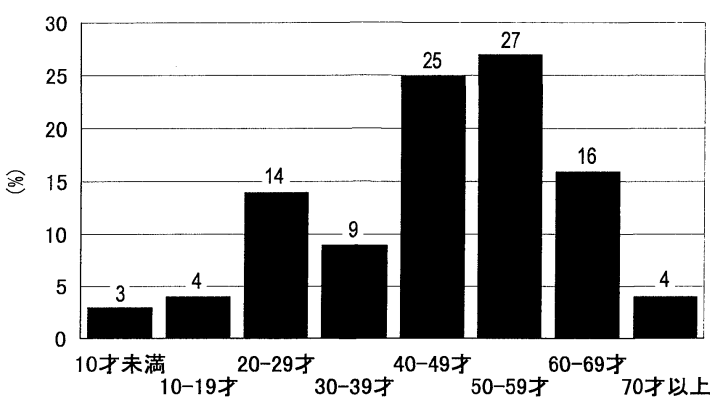

図 4 経過 10 年末満例の切断時年歯 図中の数字は\%を表す。

片側切断例 108 人中，義手を使用していない人が 9 人 $(8 \%), 1$ 種類の義手使用者が 67 人 $(62 \%), 2$ 種 類以上の義手の使用者が 32 人（28\%）であった. 義 手使用者では装飾義手が 72 人 $(66 \%)$, 能動義手が 52 人 $(47 \%)$, 内ハンド型能動義手が 25 人 (23\%), フック型能動義手が 27 人 (25\%)，作業用義手が 17 人 $(16 \%)$, 電動義手 2 人 ( $2 \%)$ であった.

\section{考察}

\section{1. 切断者の年齢について}

今回調査時の切断者の平均年齢は 55.7 歳（標準偏 差 15.3 歳）であったのに対して，1977 年の日本リ八 学会調査時の平均年齢は 26.7 歳（標準偏差 14.1 歳） であり, 今回の切断者の平均年齢は 1977 年の日本り 八学会調査よりも有意に高くなっていた $(t=28.38$, $d_{\mathrm{f}}=828, p<0.001$ ) (図 5 $)^{2)}$. 切断者年齢が高齢化し ている理由としては，大久保らが述べている高度経済 成長期の工場災害によって生じたと考えられる古い切 断例が占める比率の高いことが考えられる ${ }^{3)}$.また切 断時年齢そのものが高くなっていることが考えられる ので, 切断後 10 年末満の 110 人を抽出して, 内外の 調查報告と比較検討した。経過年数 10 年末満の 110 人の平均年齢は 45.9 歳であった。これまでの国内の 報告には今回調査に相当する切断時年齢の記述は見い だせなかったので, 1970 年のDavies ら（アメリカ） の報告平均 30.5 歳と比べると有意に高くなっていた $\left(t=6.23, d_{\mathrm{f}}=204, p<0.001\right)^{4)}$. しかし 1988 年の Pohjolainen ら (フィンランド) の 40.7 歳（標準偏差 20.0 歳 $)\left(t=1.94, d_{\mathrm{f}}=208, p>0.05\right), 1991$ 年の Gregory-Dean（イギリス）の 42.0 歳（標準偏差 19.5 歳 $)\left(t=1.47\left(d_{\mathrm{f}}=209\right)\right)$ とは差がなく, 切断時 年齢の高齢化は欧米に扔いても同様に生じていると考

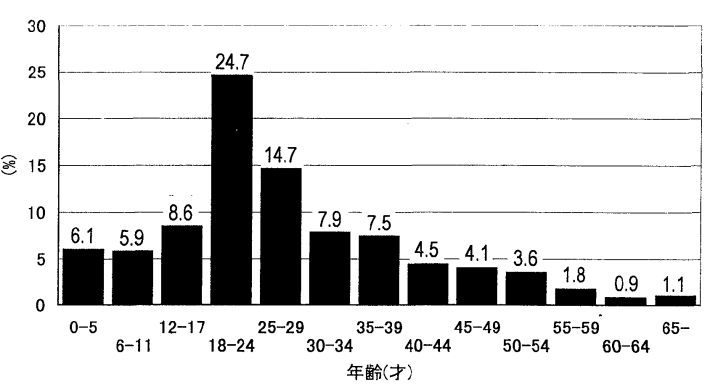

図 51977 年の日本リ八学会調査の切断者年齢2 症例数：441 人. 図中の数字は\%を表す.

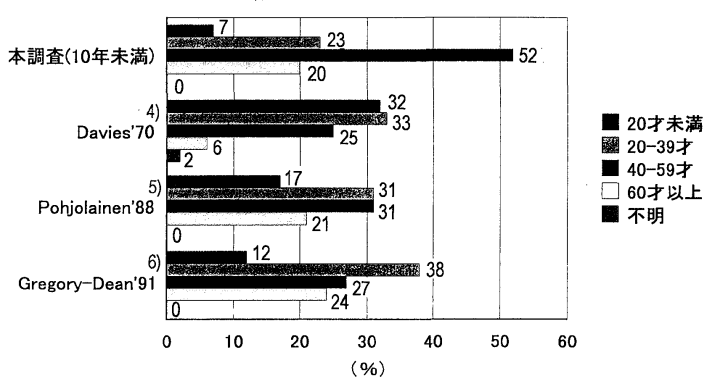

図 6 切断時年齢（従来の報告との比較） 症例数: Davies '70 572 人 Pohjolainen '88 52 人 Gregory-Dean '91 180 人 図中の数字は\%を表す.

えられる (図 6$)^{5,6)}$. 切断時年齢が高齢化する理由と しては，人口の高齢化以外に，危険作業に従事する高 齢者が増加していることも考えられるが，今回の調査 からは詳細は不明である。

\section{2. 切断後経過年数について}

切断から今回の調查までの経過年数の平均は 23.7 年であったが， 24 年前の 1973 年（昭和 48 年）は高 度経済成長期に工場災害が多発した時代の終わり頃に 相当する ${ }^{3)}$. 1997 年の岡山県の調查でも 30 年以上の 経過例が過半数を占めており7), 現在の上肢切断者は 高度成長期に切断を受けた古い切断者が中心になって いるといえるであるう。

\section{3. 切断原因と職業について}

切断原因は労働災害を主とする外傷が大多数を占 め, 先天性切断や疾病による切断恰計しても $10 \%$ 以下であった. 経過年数 10 年末満例の切断原因を 1977 年の日本リ八学会の調查結果と比較すると, 両 群の間には有意な差があり $\left(\chi^{2}=13.5, d_{\mathrm{f}}=3, p<\right.$ 0.001), 疾病の割合が減少していることが判明し 
た2).ヨーロッパの報告との比較では，1988 年の Pohjolainen ら (フィンランド) とは有意な差はなか ったが $\left(\chi^{2}=3.74, d_{\mathrm{f}}=3, p>0.05\right), 1993$ 年の Kejlaa （デンマーク）とは有意な差があって（ $\chi^{2}=37.1, d_{\mathrm{f}}=$ $3, p<0.001)$, 外傷の割合が有意に高く, 先天性切断 と疾病の割合が有意に低かった，以上を要約すると今 回調查の 10 年末満例は, 1977 年の日本リ八学会の調 査と比べて疾病の割合がむしろ減少し，ヨーロッパの 2 報告と比べると外傷の割合は高いか等しく, 先天性 切断と疾病の割合は低いか等しかった $(\text { 図 7 })^{5,8}$.

職業は切断時には過半数が現場労働であったが，調 査時点では無職が最も多かった。調査時に無職が多く なったのは，切断によって職を失った例以外に，今回 の調査例が切断からの経過年数の長い高齢者が多かっ たことも要因と考えられる7).

\section{4. 切断部位について}

今回の調査では手部の機能を全面的に袈失した「手 関節離断より近位の切断」のみを対象とした。片側切 断例の上腕切断約 30\%, 前腕切断約 $50 \%$ などの切断 部位の比率は, 従来の内外の報告と差はなかっ $た^{8 \sim 12)}$.

\section{5. 使用義手の種類について}

片側切断については，欧米でも義手をまったく使用 していない人が数\%から $30 \%$ 程度存在することが知 られている8,13,14). 本調査（全体）の $96 \%$ という非常 に高い使用率は，調査対象が義肢製作会社に登録され ている切断者であったことを考慮する必要があろう。

本調査（全体）の使用義手は, 装飾義手が圧倒的に 高い比率で使用され，能動義手，作業義手と続き，電
動義手はごく少数で，中島の報告と同様であった ${ }^{15)}$. しかし本調査の経過 10 年末満例に限って, 使用義手 の割合を 1977 年の日本リハ学会の調査報告と比較す ると, 装飾義手 $(z=1.02, p>0.05)$, 作業義手 $(z=$ $1.83, p>0.05)$, 電動義手 $(z=0.90, p>0.05)$ の割合 には変化はみられなかったが，能動義手の割合は増加 していた $(z=8.73, p<0.01)$ 』さらに 1993 年の Fraser（イギリス）と Kejlaa（デンマーク）のヨー ロッパの 2 報告をまとめたものと比較すると，本調査 の経過 10 年末満例は装飾義手の割合は有意に高く $(z=4.34, p<0.01)$, 能動義手は有意差がなく $(z=$ $1.05, p>0.05)$, 作業義手は有意に高く $(z=4.24, p<$ $0.01)$, 電動義手は有意に低かった $(z=1.99, p<$ $0.05)^{2,8,16)}$ (図 8).

なお図 8 にあげたデー夕のうち，本調査（全体およ び経過 10 年末満例）と Fraser は併用する義手（使 用義手の重複例）を含めているのに対して，日本リハ 学会と Kejlaa の報告では併用する義手を含めていな い.また近畿地区は，兵庫県立総合リハビリテーショ ンセンターによる永年にわたる能動義手の積極的な処 方および啓蒙活動によって，他の地区よりも能動義手 の使用率が高い可能性のある点に留意する必要がある $う^{15)}$.

\section{6. 義手へのニーズ}

上肢切断者が義手に対して持っているニーズは，一 般的には軽量性，高機能化，外観性向上，実用化され た場合は低価格化であるといわれる ${ }^{17,18)}$. 今回の調査 では，さらに污れの洗える義手，手首の廻る義手，断

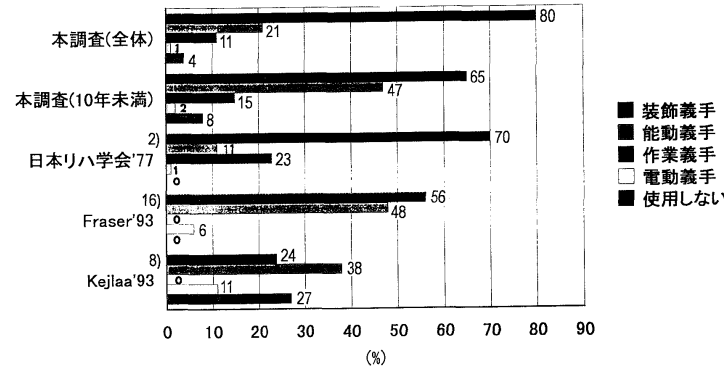

図 8 使用義手の内外文献との比較 $(\%)$ 症例数：本調査（全体） 418 人 本調查（10 年末満） 110 人 日本リハ学会 77441 人 Fraser' 93 4 Kejlaa '93 66人 図中の数字は\%を表す. 
端の蒸れないソケットへの希望があったほか, 回答者 の大多数は筋電電動義手の装着を希望した. 筋電電動 義手は機能的にも外観的にも優れ，現在の製品は重量 や動作音発生の点でも十分実用的レベルに到達してい ると考えられ，欧米ではすでに多数使用されてい $3^{19,20)}$. 今回の調査では実際の使用者は非常に少数で あったにもかかわらず，大多数の切断者が装着を希望 していた。このようなわが国における切断者のニーズ と普及の大きなギャップの最大の原因は現行の公的支 給制度と考えられるので, 一日も早い制度の改善が望 まれる。

\section{むすび}

現在の上肢切断者には高度経済成長期に生じたと推 定される経過の長い高齢切断者が多く含まれている. さらに最近の切断者には切断時の年齢の高齢化が認め られ, 装飾義手は依然として多数に使用されている が，能動義手の使用者の割合が増加していた。

これまで関係者の間では,「わが国の上肢切断者は 機能的な義手を好まず, 装飾義手しか使用しない」と 信じられてきた。しかし今回の調査結果は切断者は外 見が良くて機能的にも役に立つ義手があれば使用した いことを示しており，切断者の QOL を尊重する立場 からも, 装飾性と機能性を兼ね備えた電動義手の公的 支給の必要性を強調したい.

本調查は平成 8 年度労働省委託調査「被災労働者の特性 に応じたリフレッシュ活動の在り方等に関する調查研究」 の一部として行われた。

本調査を行うに当たり全面的なご協力をいただいた八木 義肢製作所 (京都市), (株) 近畿義肢製作所 (神戸市), 川 村義肢(株) (大阪市) の 3 社抢よびアンケートに回答をい ただいた上肢切断者の方々に感謝いたします。

本調查の統計的処理についてご指導をいただいた立命館 大学文学部心理学専攻東山篤規教授, 貴重な資料の提供を いただいた岡山大学理学療法部長島弘明助教授 (現大原町 国民健康保険病院副院長), 兵庫県立総合リハビリテーシ ヨンセンター福祉のまちづくり工学研究所北山一郎氏, 本 調査のすべての分野に打いて重要な役割を果たしていただ いた川村義肢(株)の林 律子さんに, 記して感謝の意を表 します。

\section{文献}

1）高野国夫, 小宮忠義 : 義肢需要者の実態.リハビリテー ションと技術開発 (科学技術庁計画局 監修・加藤一郎 編). 医歯薬出版, 東京, $1973 ;$ pp 51-57

2）日本リハビリテーション医学会: 第 2 章 上肢切断と 義手. 昭和 51 年度福祉関連機器の標準化推進のための
調查研究報告書. 1977 ; pp 35-81

3) 大久保衛, 島津 晃, 市川宣恭, 星 千富, 川田嘉二, 越 川 亮, 木下 孟: 大阪市身体障害者更生相談所飞お ける切断および義肢処方の実態. 臨床整形外科 1980 ; 15: $370-377$

4) Davies EJ, Fritz BR, Clippinger FW : Amputees and their prostheses. Artif Limbs $1970 ; 14(2): 19-$ 48

5) Pohjolainen $T$, Alaranta $H$ : Upper limb amputations in Southern Finland 1984-85. Ann Chir Gynaecol 1988; $77: 32-36$

6) Gregory-Dean A : Amputations : statics and trends. Ann R Coll Surg Engl 1991; 73: 137-142

7) 岡山県在宅重度身体障害者対策研究会: 岡山県在宅重 度身体障害者対策研究会報告書一義手 (No. 23). 1997

8) Kejlaa GH : Consumer concerns and the functional value of prostheses to upper limb amputees. Prosthet Orthotics Int $1993 ; \mathbf{1 7}: 157-163$

9）日下純一: 岡山県に抢ける片側上肢切断者の調查研 究. 岡山医学会誌 $1985 ; 97: 573-585$

10) Muilenburg AL, LeBlanc MA: Body-powered upper-limb components. in Comprehensive Management of the Upper-limb Amputee (ed by Atkins DJ, Meier III RH). Springer-Verlag, New York, 1989; pp 28-38

11) van Lunteren A, van Lunteren-Gerristen GHM, Stassen HG, Zuithoff MJ : Afield evaluation of arm prostheses for unilateral amputees. Prosthet Orthotics Int 1983; 7 : 141-151

12) Millstein SG, Heger H, Hunter GA : Prosthetic use in adult upper limb amputees: a comparison of the body powered and electrically powered prostheses. Prosthet Orthotics Int 1986; 10:27-34

13) Durance JP, O'Shea BJ : Upper limb amputees: a clinic profile. Int Disabil Studies 1988; 10: 68-72

14) Gaine WJ, Smart C, Bransby-Zachary M: Upper limb traumatic amputees-review of prosthetic use-. J Hand Surg 1997; 22B : 73-76

15）中島咲哉：上肢切断者に対するリハビリテーションの 実態と問題点. リ八医学 1997；34:60-69

16) Fraser $C$ : A Survey of users of upper limb prostheses. Br J Occup Ther $1993 ; \mathbf{5 6}$ (5) : 166-168

17）初山泰弘, 中島咲哉, 山崎裕功, 羽子田龍雄, 秋山昌英, 中礼光明, 田村 徹, 植木章三, 小池雅俊: 筋電電動義 手の実用化に当たっての問題点と対策に関する研究. 労働省・労働災害科学研究費・昭和 63 年度報告, 国立 身体障害者リハビリテーションセンター研究所, 1989

18）北山一郎, 幸 幹雄, 松田美穂, 中村孝義, 谷川宗明, 植 田健一郎, 西原一嘉, 古川宏, 高尾利幸, 牛尾純裕, 福 田卓美, 福伸電機(株)：装飾性及び機能性を有する義 手の開発研究. 福祉のまちづくり工学研究所報告集 1995 ; pp 61-68

19）川村次郎, 青山 孝, 古川 宏: 動力義手の最近の進歩 と臨床応用一筋電義手を中心に一。 リ八医学 1997; 34: $70-76$

20）赤澤堅造, 奥野竜平, 菊谷 功：動力義手・装具の研究 開発の現状と将来. BME 1999；13(2)：34-41 